\title{
G Antigen 1
}

National Cancer Institute

\section{Source}

National Cancer Institute. GAntigen 1. NCI Thesaurus. Code C104491.

G antigen 1 (139 aa, $\sim 16 \mathrm{kDa}$ ) is encoded by the human GAGE1 gene. This protein may be involved in tumor formation. 